\title{
TAX PROGRESSIVITY AND TAX EVASION
}

\author{
LASZLO GOERKE
}

\author{
CESIFO WORKING PAPER NO. 1097 \\ CATEGORY 4: LABOUR MARKETS \\ DECEMBER 2003
}

Presented at Venice Summer Institute, Workshop on Tax Policy and Labour Market

Performance, July 2003

\footnotetext{
An electronic version of the paper may be downloaded

- from the SSRN website: www.SSRN.com

- from the CESifo website: www.CESifo.de
} 


\title{
TAX PROGRESSIVITY AND TAX EVASION
}

\begin{abstract}
More progressive income taxes raise employment in models of imperfectly competitive labour markets. However, this prediction is not robust to modifications of the analytical structure. For example, in an efficiency wage setting, more progressive taxes reduce profits. This induces firms to exit the market such that the positive employment effect can vanish in a framework with a constant profit constraint. In this paper, it is demonstrated for an according model that tax evasion opportunities raise the likelihood of positive employment effects due to higher tax progressivity.
\end{abstract}

JEL Classification: H24, H26, J41.

Keywords: efficiency wages, employment, income tax, tax evasion, tax progressivity.

\author{
Laszlo Goerke \\ Johannes Gutenberg-University Mainz \\ Department of Economics (FB 03) \\ 55099 Mainz \\ Germany \\ Laszlo.Goerke@uni-mainz.de
}

I am grateful to Wolfgang Eggert, Manfred Holler, Burkhart Heer, participants of the annual meetings of the Verein für Socialpolitik in Innsbruck, the International Institute of Public Finance in Prague, and the CESifo Venice Summer Institute on Tax Policy and Labour Market Performance for excellent comments. I obviously retain full responsibility for all errors and omissions. 


\section{Introduction}

More progressive income taxes raise employment in models of imperfectly competitive labour markets. The basic intuition for this result is that an increase in the marginal tax rate, holding constant the level of tax payments, reduces the gain from a wage rise, while the cost of a higher wage remain the same. The notion that "tax progression is good for employment" (Koskela and Vilmunen 1996) holds for models of collective wage (and employment) determination, efficiency wage settings and also matching frameworks. ${ }^{1}$

However, the basic relationship between tax progressivity and employment is often contingent on there being solely one type of adjustment mechanism available in response to the increase in tax progressivity, namely a change in employment owing to a tax induced wage variation. If a lower wage induces other reactions than higher employment or if the alteration of the tax structure has other effects than a wage variation, then tax progressivity may no longer be good for employment. Suppose, for example, that a reduction in wage alters working hours, affects human capital formation, or alters profits. In frameworks which include such additional adjustment channels, higher tax progressivity may still reduce wages. However, lower wages need no longer entail higher aggregate employment. Instead, the wage reduction can increase working time, reduce human capital formation or the number of firms. In either of these cases, the number of workers may fall in response to an increase in tax progressivity. ${ }^{2}$

In this paper, the consequences of allowing for a further adjustment channel, that is tax evasion, are investigated. The analysis is conducted in a benchmark setting, a long-run constant profit efficiency wage economy. In this benchmark economy, an increase in tax progressivity has no employment effects in the absence of evasion opportunities. This is the case, because the higher marginal tax rate decreases wages such that effort per worker declines. Firms react to lower wages and a fall in output per worker by an increase in the number of workers. If all firms employ more workers, aggregate employment rises and effort declines further because effort is a decreasing function of unemployment. Since wages and employment are chosen optimally by each firm, the direct wage and firm-specific employment effects of higher tax progressivity have no (first-order) repercussions on profits. However, the reduction in unemployment lowers profits via the decline in effort. If profits are fixed in the long-run, some firms have to leave the market until the original level of profits is restored. This will be the case at the initial level of unemployment. ${ }^{3}$ Given the absence of

\footnotetext{
1 According results have, for example, been provided by Hoel (1990), Lockwood and Manning (1993), Goerke (1997, 1999), Malcomson and Sartor (1987), Holmlund and Kolm (1995), Bovenberg and van der Ploeg (1994), Sørensen (1997, 1999), Pissarides (1999, 2000), and Bovenberg (2003). A survey of the relevant literature is provided by Goerke (2002) who also summarises the empirical evidence.

2 Exceptions to the rule that higher income tax progressivity raises employment in models of imperfectly competitive labour markets, based on the existence of an additional adjustment mechanism, are derived by Andersen and Rasmussen (1999), Fuest and Huber (1998, 2000), Goerke (2000), Hansen et al. (2000), and Rasmussen (2002) inter alia.

3 See Goerke (2000) for the basic model, which employs the approach by Albrecht and Vroman (1996). Related issues are investigated by Fuest and Huber (1998) and Rasmussen (1998, 2002).
} 
any employment effect of higher tax progressivity in a setting without tax evasion opportunities, any positive employment impact in a world which allows for evasion activities - but is otherwise identical - would solely be due to tax evasion.

This paper shows that an employment expansion will occur if the penalty for tax evasion depends at least in part on the undeclared income, rather than solely on the amount of taxes evaded. In this case, more progressive taxes raise the gain from evasion. The worker's income rises and s/he provides higher effort. Wages can be lowered, new firms enter the market and employment increases. Accordingly, tax evasion can represent a mechanism by which the progressivity of the tax system affects the behaviour of workers and, hence, employment outcomes. Section 2 presents the model, while Section 3 analyses the employment consequences of more progressive taxes. Section 4 concludes.

Apart from analyses of tax progressivity in imperfect labour markets, this paper is related to two further strands of literature: tax evasion in efficiency wage models has been looked at by Watanabe (1996), Chang and Lai (1996) and Lai et al. (1999). These authors do not analyse tax progressivity. The impact of tax progressivity on evasion has been analysed by Koskela (1983a, b) and Trandel and Snow (1999), inter alia. In those papers, a given wage or a competitive labour market is presumed.

\section{Model}

In the economy there are a fixed number of workers whose only source of income are wages $\mathrm{w}$ and who can evade income taxes. Employed workers maximise their expected utility by choosing tax evasion activities. The (indirect) utility function $\mathrm{v}$ is strictly concave in net income, $v^{\prime}>0, v^{\prime \prime}<$ 0 . With an exogenous probability $1-\mathrm{p}$, a worker evades taxes successfully and the net income becomes $\mathrm{y}^{\mathrm{e}} \equiv \mathrm{w}-(\mathrm{w}-\mathrm{s}) \mathrm{t}(1-\mathrm{h})$, where $\mathrm{s}$ is the level of tax exemption, $0<\mathrm{s}<\mathrm{w}, \mathrm{t}$ the marginal income tax rate, $0 \leq \mathrm{t} \leq 1$, and $\mathrm{h}$ the degree of tax evasion, $0 \leq \mathrm{h} \leq 1$. With the probability $\mathrm{p}$, a worker is caught evading taxes, has to pay a penalty $\widetilde{\mathrm{F}}(\cdot)$, and obtains an income $y^{\mathrm{c}} \equiv \mathrm{y}^{\mathrm{e}}-\tilde{\mathrm{F}}(\cdot)$. In the economic analysis of tax evasion, two penalty functions have almost exclusively been analysed. Either the penalty is an increasing function of undeclared income (w - s)h (Allingham and Sandmo 1972) or of evaded taxes (w - s)th (Yitzhaki 1974). To merge the two approaches, a general penalty function $\widetilde{\mathrm{F}}(\cdot)$ is assumed which depends on a linear combination of evaded taxes and undeclared income, the relative importance of the former being measured by a parameter $\beta, 0$ $\leq \beta \leq 1$, such that $\widetilde{\mathrm{F}}(\cdot) \equiv \mathrm{F} *[(\mathrm{w}-\mathrm{s}) \mathrm{h}(1-\beta+\beta \mathrm{t})]$. Accordingly, the expected utility $\mathrm{U}(\mathrm{h})$ of an employed worker becomes:

$$
\mathrm{U}(\mathrm{h})=(1-\mathrm{p}) \mathrm{v}(\mathrm{w}-(\mathrm{w}-\mathrm{s}) \mathrm{t}(1-\mathrm{h}))+\mathrm{pv}\left(\mathrm{w}-(\mathrm{w}-\mathrm{s}) \mathrm{t}(1-\mathrm{h})-\mathrm{F}^{*}[(\mathrm{w}-\mathrm{s}) \mathrm{h}(1-\beta+\beta \mathrm{t}])\right.
$$

If tax evasion choices are unrestricted, the maximisation of expected utility (1) with respect to the optimal degree of tax evasion $\mathrm{h}$ implies:

$$
H \equiv(w-s)\left((1-p) v^{\prime}\left(y^{e}\right) t+p v^{\prime}\left(y^{c}\right)[t-F(1-\beta+\beta t)]\right)=0
$$


An interior solution requires, inter alia, $t(1-F \beta)<F(1-\beta)$, such that the ensuing restriction on $F$ varies with the penalty system, i.e. the value of $\beta$, while the second-order condition entails $\mathrm{H}_{h}<0$. The variations in the optimal degree of evasion $\mathrm{h}^{*}$, owing to a higher level of tax exemption $\mathrm{s}$ or the marginal income tax rate $t$, are governed by:

$$
\begin{aligned}
& \frac{\mathrm{H}_{\mathrm{t}}}{\mathrm{w}-\mathrm{s}}=-(1-\mathrm{p}) \mathrm{v}^{\prime \prime}\left(\mathrm{y}^{\mathrm{e}}\right) \mathrm{t}(\mathrm{w}-\mathrm{s})(1-\mathrm{h})+(1-\mathrm{p}) \mathrm{v}^{\prime}\left(\mathrm{y}^{\mathrm{e}}\right)+p \mathrm{v}^{\prime}\left(\mathrm{y}^{\mathrm{c}}\right)(1-\beta \mathrm{F}) \\
& -(w-s)\left(p v^{\prime \prime}\left(y^{c}\right)[t-F(1-\beta+\beta t)][1-h+F \beta h]\right) \\
& \frac{H_{S}}{w-s}=(1-p) v^{\prime \prime}\left(y^{e}\right) t^{2}(1-h)+p v^{\prime \prime}\left(y^{c}\right)[t-F(1-\beta+\beta t)][t(1-h)+F h(1-\beta+\beta t)]
\end{aligned}
$$

The prior analysis presumes an interior solution to a worker's tax evasion choice. However, given withholding regulations, workers may only be able to select a value of $h$ such that $h<h^{*}$. Moreover, withholding regulations would prevent adjustments in evasion activities in response to a change of tax progressivity. Both cases, an optimally chosen $\left(h=h^{*}\right)$ and an exogenously given degree of tax evasion $(\mathrm{h}<\mathrm{h} *)$ are investigated below. This distinction proves to have an impact on the employment consequences of more progressive taxes.

In the framework set out above, the effort of a worker is determined by an exogenously given effort function e. Since the impact of tax evasion on work effort is not well documented, two distinct functions are considered. Effort $\mathrm{e}$ is assumed to increase with the unemployment rate $\mathrm{u}\left(\mathrm{e}_{\mathrm{u}}>\right.$ 0 , a subscript indicating a partial derivative) and to be either a function of the income $y^{e}$ in the case of successful tax evasion, $\mathrm{e}=\tilde{\mathrm{e}}\left(\mathrm{y}^{\mathrm{e}}, \mathrm{u}\right)$, or alternatively of the expected utility if employed $\mathrm{U}, \mathrm{e}=$ $\hat{\mathrm{e}}(\mathrm{U}, \mathrm{u})$. The effort functions are strictly concave in their first arguments. The rationale for the effort function $\mathrm{e}=\tilde{\mathrm{e}}\left(\mathrm{y}^{\mathrm{e}}, \mathrm{u}\right)$ is that a penalty on which the firm has no (direct) influence does not affect the worker's performance. The second specification, $\mathrm{e}=\hat{\mathrm{e}}(\mathrm{U}, \mathrm{u})$, will be more appropriate if expected utility determines effort, irrespective of its source. Given these restrictions on e, effort is strictly concave in wages $\mathrm{w}\left(\mathrm{e}_{\mathrm{W}}>0, \mathrm{e}_{\mathrm{ww}}<0\right)$. To make results, furthermore, comparable to those of other studies on the employment consequences of more progressive taxes in an efficiency wage setting, which generally assume that the equilibrium wage declines with unemployment $\mathrm{u}$, entailing $\mathrm{dw} / \mathrm{du}=\left(\mathrm{e}_{\mathrm{u}}-\mathrm{we}_{\mathrm{wu}}\right) /\left(\mathrm{we}_{\mathrm{ww}}\right)<0$ (cf. Hoel 1990), for simplicity the cross-derivatives of the effort function are assumed to be zero, i.e. $\tilde{\mathrm{e}}_{\mathrm{y}} \mathrm{e}_{\mathrm{u}}=\hat{\mathrm{e}}_{\mathrm{Uu}}=0$ is presumed.

In the economy, there are many ex-ante identical firms with a constant capital stock and characterised by a production function $\mathrm{f}$ which is strictly concave in efficiency units of labour, $\mathrm{f}$ '(en) $>0, \mathrm{f} "<0, \mathrm{n}$ being employment per firm. The output price of the homogeneous good is unity. As usual in simple efficiency wage models, firms choose wages and employment optimally (Solow 1979), such that wages are determined by the Solow-condition, $\mathrm{e}-\mathrm{we}_{\mathrm{W}}=0$. In addition, in the present setting the number of firms is endogenous and regulated by a constant or zero profit situation. Accordingly, the framework may be regarded as describing a long-run equilibrium. For simplicity, however, entry and exit decisions are not modelled. Finally, note that aggregate labour demand is determined by the profit constraint $\pi=0$. 


\section{More Progressive Income Tax System}

In a setting without tax evasion opportunities, an increase in tax progressivity, i.e. a combined rise of the marginal income tax rate $t$ and the level of tax exemption $s$, holding constant taxes at the original wage, will lower unemployment if firms are profitable, while there not be any employment effect in the case of constant profits (Goerke 2000). These differential employment effects of higher tax progressivity result since the decrease in unemployment in an efficiency wage setting occurs at the expense of lower profits. To illustrate this claim, let higher tax progressivity be tantamount to an increase in the level of income tax exemption $\mathrm{s}$ and assume that unemployment $\mathrm{u}$ declines with tax progressivity, implying $\partial u / \partial s<0$. Since firms choose wages and employment optimally, the profit effect of higher tax progressivity is found to be unambiguously negative:

$$
\frac{\mathrm{d} \pi}{\mathrm{ds}}=\left[\frac{\partial \pi}{\partial \mathrm{n}}+\frac{\partial \pi}{\partial \mathrm{n}} \frac{\partial \mathrm{n}}{\partial \mathrm{w}}\right] \frac{\partial \mathrm{w}}{\partial \mathrm{s}}+\frac{\partial \pi}{\partial \mathrm{e}} \mathrm{e}_{\mathrm{u}} \frac{\partial \mathrm{u}}{\partial \mathrm{s}}<0
$$

If some firms react to the decline in profits by leaving the market, the reduction in the number of firms will exactly balance the rise in the number of workers per firm such that the overall employment effect is zero. These results imply that if a zero profit constraint in an efficiency wage economy is combined with a tax reform which leaves constant the level of statutory tax payments $(\mathrm{w}-\mathrm{s}) \mathrm{t}$ at the initial wage, any employment effect of tax progressivity will entirely be attributable to tax evasion opportunities.

The economic system which governs the employment effects of higher income tax progressivity is defined by the Solow-condition $\mathrm{e}-\mathrm{we}_{\mathrm{W}}=0$ and the profit constraint $\pi=0$. The level of tax exemption $\mathrm{s}$ represents the policy parameter. Total differentiation, taking into account that the marginal income tax rate $t$ varies with the level of tax exemption $s$ to allow for constant statutory tax payments, such that $d t / d s=t /(w-s)$, while $w$ and $u$ are the endogenous variables, yields:

$$
\left[\begin{array}{cc}
-\mathrm{we}_{\mathrm{ww}} & \mathrm{e}_{\mathrm{u}} \\
0 & \mathrm{f}^{\prime} \mathrm{e}_{\mathrm{u}} \mathrm{n}
\end{array}\right]\left[\begin{array}{c}
\mathrm{dw} \\
\mathrm{du}
\end{array}\right]=\left[\begin{array}{c}
-\mathrm{e}_{\mathrm{s}}+\mathrm{we}_{\mathrm{ws}}-\left(\mathrm{e}_{\mathrm{t}}-\mathrm{we}_{\mathrm{wt}}\right) \frac{\mathrm{dt}}{\mathrm{ds}} \\
-\mathrm{f}^{\prime} \mathrm{n}\left(\mathrm{e}_{\mathrm{s}}+\mathrm{e}_{\mathrm{t}} \frac{\mathrm{dt}}{\mathrm{ds}}\right)
\end{array}\right][\mathrm{ds}]
$$

Accordingly, the unemployment effect of a more progressive tax system is given by:

$$
\frac{\mathrm{du}}{\mathrm{ds}}=-\frac{\mathrm{Z}}{(\mathrm{w}-\mathrm{s}) \mathrm{e}_{\mathrm{u}}} \text {, where } \mathrm{Z} \equiv \mathrm{e}_{\mathrm{s}}(\mathrm{w}-\mathrm{s})+\mathrm{te}_{\mathrm{t}}
$$

The sign of $\mathrm{Z}$ depends, inter alia, on the nature of the effort function. If effort is determined by the income of successful evasion, $\mathrm{e}=\tilde{\mathrm{e}}\left(\mathrm{y}^{\mathrm{e}}, \mathrm{u}\right)$ will hold, and $\mathrm{e}_{\mathrm{t}}$ and $\mathrm{e}_{\mathrm{S}}$ are found to be:

$$
\begin{aligned}
& \mathrm{e}_{\mathrm{t}}=\tilde{\mathrm{e}}_{\mathrm{y}} \mathrm{e}(\mathrm{w}-\mathrm{s})\left(\mathrm{th}_{\mathrm{t}}^{*}-(1-\mathrm{h})\right) \\
& \mathrm{e}_{\mathrm{s}}=\tilde{\mathrm{e}}_{\mathrm{y}} \mathrm{e} t\left((1-\mathrm{h})+(\mathrm{w}-\mathrm{s}) \mathrm{h}_{\mathrm{s}}^{*}\right)
\end{aligned}
$$

In equations (8) and (9), the derivatives of $h^{*}$ represent the adjustment in the optimal degree of tax evasion. For an exogenously given degree of tax evasion $(\mathrm{dh}=0)$, the terms involving these 
derivatives will drop out if the optimal value of $h$ subsequent to the tax reform is still above the feasible degree of evasion. From equations (7) to (9) it can then be seen by setting $h=d h=0$, i. e. by assuming a framework without evasion opportunities, that there is no change in employment due to an increase in tax progressivity. Hence, the employment effects of higher tax progressivity in a world with an exogenously given degree of tax evasion $\left(\mathrm{h}<\mathrm{h}^{*}\right)$ are the same as in a setting without tax evasion. The intuition for the equivalence is that the tax reform does not alter effort due to the assumption of a given tax level. Moreover, there is no effect of tax progressivity on evasion - by assumption since $\mathrm{dh}=0$. Hence, effort is unaffected, while profits and employment remain constant.

Assuming optimal evasion activities, the unemployment effect of higher tax progressivity becomes:

$$
\begin{aligned}
\mathrm{Z} \mid \mathrm{e}=\tilde{\mathrm{e}}\left(\mathrm{y}^{\mathrm{e}}, \mathrm{u}\right), \mathrm{h}=\mathrm{h}^{*}= & \tilde{\mathrm{e}}_{\mathrm{y}} \mathrm{e}\left((\mathrm{w}-\mathrm{s}) \mathrm{h}_{\mathrm{s}}^{*}+\mathrm{th}_{\mathrm{t}}^{*}\right)(\mathrm{w}-\mathrm{s}) \mathrm{t} \\
= & -\frac{\tilde{\mathrm{e}}_{\mathrm{y}}^{\mathrm{e}}}{\mathrm{H}_{\mathrm{h}}}\left((\mathrm{w}-\mathrm{s}) \mathrm{H}_{\mathrm{S}}+\mathrm{tH}_{\mathrm{t}}\right)(\mathrm{w}-\mathrm{s}) \mathrm{t} \\
= & -\frac{(\mathrm{w}-\mathrm{s})^{3} \mathrm{te}_{\mathrm{y}}^{\mathrm{e}}}{\mathrm{H}_{\mathrm{h}}} \mathrm{pv^{ \prime \prime }}\left(\mathrm{y}^{\mathrm{c}}\right)[\mathrm{t}-\mathrm{F}(1-\beta+\beta \mathrm{t})] \mathrm{Fh}(1-\beta) \\
& \quad-\frac{(\mathrm{w}-\mathrm{s})^{2} \mathrm{t}^{2} \tilde{\mathrm{e}}_{\mathrm{y}^{\mathrm{e}}}\left\{(1-\mathrm{p}) \mathrm{v}^{\prime}\left(\mathrm{y}^{\mathrm{e}}\right)+\mathrm{pv} \mathrm{v}^{\prime}\left(\mathrm{y}^{\mathrm{c}}\right)(1-\beta \mathrm{F})\right\}>0, \text { if } \beta<1}{\mathrm{H}_{\mathrm{h}}}
\end{aligned}
$$

If the penalty depends at least in part on undeclared income $\beta<1$ ), an interior solution to the evasion problem (cf. equation (2)) ensures that the term in square brackets subsequent to the last equality sign in (10) is negative, while the expression in curly brackets is greater than zero. Accordingly, the optimal degree of tax evasion $h^{*}$ rises because a more progressive income tax reduces the penalty. ${ }^{4}$ Higher tax evasion increases the income of successful evasion $y^{\mathrm{e}}$ and thereby effort. Greater effort allows firms to reduce the wage and to increase employment; implying $\mathrm{Z}>0$ and $\mathrm{du} / \mathrm{ds}<0$.

In an efficiency wage economy with variable profits but without tax evasion, higher statutory tax progressivity at the initial wage reduces the firm's incentives to raise wages, because the increase in effort due to higher wages is mitigated by the higher marginal income tax rate. Lower wages result in a reduction of effort and in lesser profits and greater employment. If firms face a (zero) profit

\footnotetext{
4 This can be seen most clearly by rewriting the penalty as $\mathrm{F}(\cdot)=\mathrm{F}^{*} \mathrm{~h}[\beta(\mathrm{w}-\mathrm{s}) \mathrm{t}+(1-\beta)(\mathrm{w}-\mathrm{s})]$ and is due to the fact that an increase in the level of tax exemption s lowers undeclared income. For a given statutory tax burden $(\mathrm{w}-\mathrm{s}) \mathrm{t}$ and a given degree of evasion $\mathrm{h}^{*}$, the penalty declines. See also Koskela (1983b), who shows for a model with exogenous income that tax evasion will rise with an increase in tax progressivity if the fine is a function of undeclared income, and the government's expected tax revenues or the worker's expected utility are held constant.
} 
constraint, the reduction in profits causes some firms to leave the market such that unemployment rises until profits have attained their original level again. A new equilibrium is reached at the old level of employment, with fewer firms each having more workers (Goerke 2000). In the presence of tax evasion, the change in statutory tax progressivity induces workers to provide more effort at a given wage and unemployment level for $\beta<1$, because evasion activities intensify. Thus, profits rise. Employment increases until profits have fallen to the pre-tax reform level of zero. Given these differential effects for a model without evasion and a setting with tax evasion opportunities, the employment expansion is solely due to the existence of tax evasion.

Turning to the effort function $\mathrm{e}=\hat{\mathrm{e}}(\mathrm{U}, \mathrm{u})$, the derivatives with respect to the marginal income tax rate and the level of tax exemption are given by:

$$
\begin{aligned}
& e_{t}=-\hat{e}_{U}(w-s)\left[(1-p) v^{\prime}\left(y^{e}\right)(1-h)+p v^{\prime}\left(y^{c}\right)\{1-h+F \beta h\}\right]+\hat{e}_{U} H h_{t}^{*} \\
& e_{s}=\hat{e}_{U}\left[(1-p) v^{\prime}\left(y^{e}\right) t(1-h)+p v^{\prime}\left(y^{c}\right)\{t(1-h)+F(1-\beta+\beta t) h\}\right]+\hat{e}_{U} H^{*}{ }_{s}^{*}
\end{aligned}
$$

Using equations (7), (11), and (12), the change in unemployment due to higher tax progressivity is found to be:

$$
\left.\frac{\mathrm{du}}{\mathrm{ds}}\right|_{\mathrm{e}=\hat{\mathrm{e}}(\mathrm{U}, \mathrm{u})}=-\frac{\hat{\mathrm{e}}_{\mathrm{Upv}}\left(\mathrm{y}^{\mathrm{c}}\right) \mathrm{hF}(1-\beta)}{\hat{\mathrm{e}}_{\mathrm{u}}}<0 \text {, if } \beta<1
$$

This result is independent of whether evasion choices are optimal or not, since an optimal selection implies $\mathrm{H}=0$, while an exogenously determined degree of tax evasion entails $\mathrm{dh}^{*}=0$. Accordingly, the last terms in equations (11) and (12) drop out, irrespective of whether evasion activities are optimal $\left(h=h^{*}\right)$ or restricted exogenously $\left(h<h^{*}\right)$. The reason for the positive impact of higher tax progressivity on employment is that a greater level of tax exemption $s$ affects all payoffs equally. However, if the penalty also depends on undeclared income, implying $\beta<1$, a higher marginal income tax rate $t$ will raise the penalty by less than the increase in the level of tax exemption s will reduce it. This implies a lower penalty. Expected income and effort rise. Higher effort allows for a reduction in wages and induces a fall in unemployment.

The findings can be summarised as follows: a more progressive income tax system, holding constant the statutory tax level at the initial wage, will reduce unemployment in a constant profit efficiency wage economy if the penalty for tax evasion depends at least marginally on undeclared income and either effort is a function of the expected utility of an employed worker or effort rises with the income of successful evasion while evasion choices are unrestricted.

\section{Discussion}

The employment effects of more progressive taxes in an efficiency wage economy have been analysed in the presence of tax evasion in a setting in which such policy changes have no employment consequences in the absence of evasion. If the penalty for evasion is influenced by undeclared 
income and tax evasion choices are unrestricted, then a rise in statutory tax progressivity increases employment and tax evasion can be argued to re-establish the positive employment impact of more progressive income taxes. If evasion choices are restricted, for example, due to withholding regulations, the employment effects of higher statutory tax progressivity depend on the nature of the effort function.

The analysis has presumed a constant level of statutory tax payments at the initial wage level. However, any employment change due to the penalty also being an increasing function of undeclared income requires adjustments in evasion behaviour and, therefore, in the efficiency wage. Accordingly, constant statutory tax payments neither guarantee the expected income of workers, nor expected tax payments, nor a balanced budget. If an increase in tax progressivity is combined with the requirement of either constant tax payments or a balanced-budget, the positive employment effects of higher tax progressivity can no longer be ascertained, even in the absence of tax evasion (cf. Fuest and Huber 1998 or Rasmussen 2002). This ambiguity is aggravated in the presence of tax evasion because wage changes affect evasion behaviour which, in turn, alters the level of effort. As the impact of tax variations on effort, taking into account direct tax and indirect wage and evasion effects, cannot be determined unambiguously, the employment consequences of tax reforms become uncertain. 


\section{References}

Albrecht, James W. and Susan B. Vroman (1996), A Note on the Long-run Properties of the Shirking Model, Labour Economics 3, 189-195.

Allingham, Michael G. and Agnar Sandmo (1972), Income Tax Evasion: A Theoretical Analysis, Journal of Public Economics 1, 323-338.

Andersen, Torben M. and Bo Sandemann Rasmussen (1999), Effort, Taxation and Unemployment, Economics Letters 62, 97-103.

Bovenberg, A. Lars and Frederick van der Ploeg (1994), Effects of the Tax and Benefit System on Wage Formation and Unemployment, Mimeo.

Chang, Wen-Ya and Ching-Chong Lai (1996), The Implication of Efficiency Wages on Tax Evasion and Tax Collections, Public Finance Quarterly 24, 163-172.

Fuest, Clemens and Bernd Huber (1998), Efficiency Wages, Employment, and the Marginal Income-tax Rate: a Note, Journal of Economics 68, 79-84.

Fuest, Clemens and Bernd Huber (2000), Is Tax Progression Really Good for Employment? A Model with Endogenous Hours of Work, Labour Economics 7, 79-93.

Goerke, Laszlo (1997), An Open Shop, Wage Bargaining, and Taxation - A Note, Oxford Economic Papers 49, 651-657.

Goerke, Laszlo (1999), Efficiency Wages and Taxes, Australian Economic Papers 38, 131142.

Goerke, Laszlo (2000), Employment, Taxation, Efficiency Wages, and the Long-run, Bulletin of Economic Research 52, 341-352.

Goerke, Laszlo (2002), Taxes and Unemployment, Kluwer Academic Publishers: Boston et al.. Hansen, Claus Thustrup, Pedersen, Lars-Haagen and Torsten Sløk (2000), Ambiguous Effects of Tax Progression - Theory and Danish Evidence, Labour Economics 7, 335-347.

Hoel, Michael (1990), Efficiency Wages and Income Taxes, Journal of Economics 51, 89-99.

Holmlund, Bertil and Ann-Sofie Kolm (1995), Progressive Taxation, Wage Setting and

Unemployment: Theory and Swedish Evidence, Swedish Economic Policy Review 2, 423-460.

Koskela, Erkki (1983a), A Note on Progression, Penalty Schemes and Tax Evasion, Journal of

Public Economics 22, 127-133.

Koskela, Erkki (1983b), On the Shape of Tax Schedule, the Probability of Detection, and the Penalty Schemes as Deterrents to Tax Evasion, Public Finance/ Finances Publiques 38, 70-80.

Lai, Ching-Chong, Chang, Juin-Jen and Chung-Cheng Lin (1999), Income Tax Evasion in a Shirking Model of Efficiency Wages, Mimeo.

Lockwood, Ben and Alan Manning (1993), Wage Setting and the Tax System, Journal of Public Economics 52, 1-29.

Malcomson, Jim and Nicola Sartor (1987), Tax Push Inflation in a Unionized Labour Market, European Economic Review 31,1581-1596.

Pissarides, Christopher A. (1999), Policy Influences on Unemployment: The European Context, Scottish Journal of Political Economy 46, 389-418.

Pissarides, Christopher A. (2000), Equilibrium Unemployment Theory, ( $2^{\text {nd }}$ ed.), The MIT Press: Cambridge (Mass.) and London.

Rasmussen, Bo Sandemann (1998), Long Run Effects of Employment and Payroll Taxes in an Efficiency Wage Model, Economics Letters 58, 245-253. 
Rasmussen, Bo Sandemann (2002), Efficiency Wages and the Long-run Incidence of Progressive Taxation, Journal of Economics 76, 155-175.

Solow, Robert M. (1979), Another Possible Source of Wage Stickiness, Journal of Macroeconomics $1,79-82$.

Sørensen, Peter Birch (1997), Public Finance Solutions to the European Unemployment Problem, Economic Policy 12, 223-264.

Sørensen, Peter Birch (1999), Optimal Tax Progressivity in Imperfect Labour Markets, Labour Economics 6, 435-452.

Trandel, Greg and Arthur Snow (1999), Progressive Income Taxation and the Underground Economy, Economics Letters 62, 217-222.

Watanabe, Shigeru (1996), A Note on a Basic Model of Efficiency Wage and Tax Evasion, Bulletin of University of Osaka Prefecture 40, 43-47.

Yitzhaki, Shlomo (1974), A Note on Income Tax Evasion: A Theoretical Analysis, Journal of Public Economics 3, 201-202. 


\section{CESifo Working Paper Series}

(for full list see www.cesifo.de)

1031 Ivar Ekeland, James J. Heckman, and Lars Nesheim, Identifcation and Estimation of Hedonic Models, September 2003

1032 Kjetil Bjorvatn and Alexander W. Cappelen, Decentralization and the Fate of Minorities, September 2003

1033 Lars-Erik Borge and Jørn Rattsø, The Relationships Between Costs and User Charges: The Case of a Norwegian Utility Service, September 2003

1034 Maureen Were and Nancy N. Nafula, An Assessment of the Impact of HIV/AIDS on Economic Growth: The Case of Kenya, September 2003

1035 A. Lans Bovenberg, Tax Policy and Labor Market Performance, September 2003

1036 Peter Birch Sørensen, Neutral Taxation of Shareholder Income: A Norwegian Tax Reform Proposal, September 2003

1037 Roberta Dessi and Sheilagh Ogilvie, Social Capital and Collusion: The Case of Merchant Guilds, September 2003

1038 Alessandra Casarico and Carlo Devillanova, Capital-skill Complementarity and the Redistributive Effects of Social Security Reform, September 2003

1039 Assaf Razin and Efraim Sadka, Privatizing Social Security Under Balanced-Budget Constraints: A Political-Economy Approach, September 2003

1040 Michele Moretto, Paolo M. Panteghini, and Carlo Scarpa, Investment Size and Firm's Value under Profit Sharing Regulation, September 2003

1041 A. Lans Bovenberg and Peter Birch Sørensen, Improving the Equity-Efficiency Tradeoff: Mandatory Savings Accounts for Social Insurance, September 2003

1042 Bas van Aarle, Harry Garretsen, and Florence Huart, Transatlantic Monetary and Fiscal Policy Interaction, September 2003

1043 Jerome L. Stein, Stochastic Optimal Control Modeling of Debt Crises, September 2003

1044 Thomas Stratmann, Tainted Money? Contribution Limits and the Effectiveness of Campaign Spending, September 2003

1045 Marianna Grimaldi and Paul De Grauwe, Bubbling and Crashing Exchange Rates, September 2003 
1046 Assar Lindbeck and Dennis J. Snower, The Firm as a Pool of Factor Complementarities, September 2003

1047 Volker Grossmann, Firm Size and Diversification: Asymmetric Multiproduct Firms under Cournot Competition, September 2003

1048 Dan Anderberg, Insiders, Outsiders, and the Underground Economy, October 2003

1049 Jose Apesteguia, Steffen Huck and Jörg Oechssler, Imitation - Theory and Experimental Evidence, October 2003

1050 G. Abío, G. Mahieu and C. Patxot, On the Optimality of PAYG Pension Systems in an Endogenous Fertility Setting, October 2003

1051 Carlos Fonseca Marinheiro, Output Smoothing in EMU and OECD: Can We Forego Government Contribution? A Risk Sharing Approach, October 2003

1052 Olivier Bargain and Nicolas Moreau, Is the Collective Model of Labor Supply Useful for Tax Policy Analysis? A Simulation Exercise, October 2003

1053 Michael Artis, Is there a European Business Cycle?, October 2003

1054 Martin R. West and Ludger Wößmann, Which School Systems Sort Weaker Students into Smaller Classes? International Evidence, October 2003

1055 Annette Alstadsaeter, Income Tax, Consumption Value of Education, and the Choice of Educational Type, October 2003

1056 Ansgar Belke and Ralph Setzer, Exchange Rate Volatility and Employment Growth: Empirical Evidence from the CEE Economies, October 2003

1057 Carsten Hefeker, Structural Reforms and the Enlargement of Monetary Union, October 2003

1058 Henning Bohn and Charles Stuart, Voting and Nonlinear Taxes in a Stylized Representative Democracy, October 2003

1059 Philippe Choné, David le Blanc and Isabelle Robert-Bobée, Female Labor Supply and Child Care in France, October 2003

1060 V. Anton Muscatelli, Patrizio Tirelli and Carmine Trecroci, Fiscal and Monetary Policy Interactions: Empirical Evidence and Optimal Policy Using a Structural New Keynesian Model, October 2003

1061 Helmuth Cremer and Pierre Pestieau, Wealth Transfer Taxation: A Survey, October 2003

1062 Henning Bohn, Will Social Security and Medicare Remain Viable as the U.S. Population is Aging? An Update, October 2003

1063 James M. Malcomson, Health Service Gatekeepers, October 2003 
1064 Jakob von Weizsäcker, The Hayek Pension: An efficient minimum pension to complement the welfare state, October 2003

1065 Joerg Baten, Creating Firms for a New Century: Determinants of Firm Creation around 1900, October 2003

1066 Christian Keuschnigg, Public Policy and Venture Capital Backed Innovation, October 2003

1067 Thomas von Ungern-Sternberg, State Intervention on the Market for Natural Damage Insurance in Europe, October 2003

1068 Mark V. Pauly, Time, Risk, Precommitment, and Adverse Selection in Competitive Insurance Markets, October 2003

1069 Wolfgang Ochel, Decentralising Wage Bargaining in Germany - A Way to Increase Employment?, November 2003

1070 Jay Pil Choi, Patent Pools and Cross-Licensing in the Shadow of Patent Litigation, November 2003

1071 Martin Peitz and Patrick Waelbroeck, Piracy of Digital Products: A Critical Review of the Economics Literature, November 2003

1072 George Economides, Jim Malley, Apostolis Philippopoulos, and Ulrich Woitek, Electoral Uncertainty, Fiscal Policies \& Growth: Theory and Evidence from Germany, the UK and the US, November 2003

1073 Robert S. Chirinko and Julie Ann Elston, Finance, Control, and Profitability: The Influence of German Banks, November 2003

1074 Wolfgang Eggert and Martin Kolmar, The Taxation of Financial Capital under Asymmetric Information and the Tax-Competition Paradox, November 2003

1075 Amihai Glazer, Vesa Kanniainen, and Panu Poutvaara, Income Taxes, Property Values, and Migration, November 2003

1076 Jonas Agell, Why are Small Firms Different? Managers’ Views, November 2003

1077 Rafael Lalive, Social Interactions in Unemployment, November 2003

1078 Jean Pisani-Ferry, The Surprising French Employment Performance: What Lessons?, November 2003

1079 Josef Falkinger, Attention, Economies, November 2003

1080 Andreas Haufler and Michael Pflüger, Market Structure and the Taxation of International Trade, November 2003

1081 Jonas Agell and Helge Bennmarker, Endogenous Wage Rigidity, November 2003 
1082 Fwu-Ranq Chang, On the Elasticities of Harvesting Rules, November 2003

1083 Lars P. Feld and Gebhard Kirchgässner, The Role of Direct Democracy in the European Union, November 2003

1084 Helge Berger, Jakob de Haan and Robert Inklaar, Restructuring the ECB, November 2003

1085 Lorenzo Forni and Raffaela Giordano, Employment in the Public Sector, November 2003

1086 Ann-Sofie Kolm and Birthe Larsen, Wages, Unemployment, and the Underground Economy, November 2003

1087 Lars P. Feld, Gebhard Kirchgässner, and Christoph A. Schaltegger, Decentralized Taxation and the Size of Government: Evidence from Swiss State and Local Governments, November 2003

1088 Arno Riedl and Frans van Winden, Input Versus Output Taxation in an Experimental International Economy, November 2003

1089 Nikolas Müller-Plantenberg, Japan’s Imbalance of Payments, November 2003

1090 Jan K. Brueckner, Transport Subsidies, System Choice, and Urban Sprawl, November 2003

1091 Herwig Immervoll and Cathal O'Donoghue, Employment Transitions in 13 European Countries. Levels, Distributions and Determining Factors of Net Replacement Rates, November 2003

1092 Nabil I. Al-Najjar, Luca Anderlini \& Leonardo Felli, Undescribable Events, November 2003

1093 Jakob de Haan, Helge Berger and David-Jan Jansen, The End of the Stability and Growth Pact?, December 2003

1094 Christian Keuschnigg and Soren Bo Nielsen, Taxes and Venture Capital Support, December 2003

1095 Josse Delfgaauw and Robert Dur, From Public Monopsony to Competitive Market. More Efficiency but Higher Prices, December 2003

1096 Clemens Fuest and Thomas Hemmelgarn, Corporate Tax Policy, Foreign Firm Ownership and Thin Capitalization, December 2003

1097 Laszlo Goerke, Tax Progressivity and Tax Evasion, December 2003 